\title{
Self-denigrating actions
}

Congratulations on one of the Best editorials I've read in my 35 years in pharmacy. Thanks for enumerating a few "actions that defame our profession."1 Personally, I think there are more than that. There are still some "snake-oil vendors" in our own profession who are not convinced that pharmacy is a science-based profession. Thanks to pharmacists like you who are trying to push our profession forward with evidence-based pharmacy.
Continue your good work!

-Vincent J. Basque

Moncton, NB

\section{Reference}

1. Davies NM, Tsuyuki RT. Self-denigration in pharmacy: actions that should be curtailed. Can Pharm J (Ott) 2014;147:265-6.

(C) The Author(s) 2014

DOl: $10.1177 / 1715163514561604$

\section{Self-denigrating actions}

While I APPLAUd THE MAJORITY OF Drs. DAVIES AND TsUyukI's suggestions, I must take exception to their views on pharmacy drive-through windows. No doubt there are examples of poor practice using this technology, but we built our window with the intention of improving patient access and quality of care. Our experience has been that it has enhanced the quality of patient interaction for many patients, most notably those with mobility issues and mothers with children. Snow accumulations and icy sidewalks in our northern city mean that even businesses that are wheelchair-accessible in summer can be tricky to access during the winter months. People who have an acute injury are likely safer staying in a vehicle rather than navigating their way into the pharmacy on crutches. Many mothers solo-parent while their partners work in the oil patch and are grateful for the drivethrough window, especially in sub $-20^{\circ} \mathrm{C}$ weather: They don't have to unload babies or children and keep an eye on them in a distracting pharmacy while trying to listen to the pharmacist.

While the drive-through window does present some communication and confidentiality challenges, the fact that we actually speak to the patient rather than a third party means the patient is able to ask questions and clarify issues directly with us. Febrile patients can receive direct counselling while not mingling with other patients in the pharmacy. Patients smoking in their vehicles have occasioned some productive counselling when no such opportunity would have existed in-store. The idling issue is valid (although I suspect it is no worse than for those patients who leave their vehicles running while they wait in a pharmacy), and we strongly urge drivers to turn their engines off while at the drive-through window.

The drive-through window is just another technology in our armory of care. Used properly, it confers great benefit on our patients and reflects well on our practice and profession.

-Michael Ortynsky, BSc(Pharm) Fort St. John, British Columbia

\section{Reference}

1. Davies NM, Tsuyuki RT. Self-denigration in pharmacy: actions that should be curtailed. Can Pharm J (Ott) 2014;147:265-6.

(C) The Author(s) 2014

DOI: $10.1177 / 1715163514561605$

\section{Self-denigration in pharmacy}

In RESPONSE TO THE EDITORIALS By DRs. DAVIES AND TSUYuki on self-denigrating words and actions in pharmacy, ${ }^{1,2}$ I do agree that change is required, at the grassroots level, but I don't agree with some of the statements made by the authors.
Many of the issues highlighted as self-denigrating relate to factors that are in many respects uncontrollable for most community pharmacists, that is, the nature of the environment itself. And while one may state "that's why we should limit 
ownership to pharmacists," this is in place in Australia yet the same "issues" are present.

The definition of allied is "joined in a relationship in which people, groups, countries, etc., agree to work together"3 - what's wrong with this term? I don't believe it connotes a secondary role. As well, I'm not sure how many pharmacists would ever refer to themselves as "retail" pharmacists; it's either pharmacist or community pharmacist. Those who work in a hospital are almost always sure to distinguish themselves as hospital pharmacists.

"Minor ailments" do not mean "insignificant" ailments, and this term is integrated into legislation in many jurisdictions. ${ }^{4,5}$ By pledging to avoid the term minor ailment in CPJ going forward, does this mean that those in the profession wanting to disseminate findings on these ailments in various jurisdictions must look to publish elsewhere?

With regard to drive-through pharmacies, I too used to think they served no purpose in community pharmacy practice, until someone asked me where I would prefer to have counselling done on a potentially embarrassing condition-in the pharmacy itself, with other patients right behind me, or in the privacy of my own vehicle? Furthermore, if you were a parent with a child who had otitis media and was in pain, wouldn't you rather stay in your own vehicle with your child (or children) while the antibiotic was being filled?

The environment of the community pharmacy itself is what dictates many of the "stereotypes" mentioned in the editorials. How many physicians or dentists provide the opportunity to purchase pop, chips, chocolate bars and other unhealthy fare along with a metformin prescription and a professional health care service? This retail environment means that patients do not always see themselves that way, with as many as two-thirds of patients viewing themselves as customers. ${ }^{6-8}$

Perhaps the profession would be best served by professional and advocacy organizations arming individual pharmacists with the tools and resources to advocate for better recognition of what pharmacists are and can do, highlighting the true value of pharmacists. There are examples of pharmacists going to politicians and providing professional services to inform them of the role pharmacists play and the value of pharmacists ${ }^{9,10}$ and of organizations that provide grassroots advocacy resources for pharmacists, turning them into frontline advocates. ${ }^{11,12}$ Instead of saying that the medication review you just completed for a patient is "free," why not let the patient know the value the government has placed on the service (e.g., \$60)?

Why not invite your local MP, MLA, MPP or municipal leaders into your pharmacy to show them what pharmacists are doing and where they add value to patients and the system? This would help develop and nurture a long-term relationship. Being reactive instead of proactive will almost always result in a less than desirable outcome and will use a lot more resources.

-Jason Perepelkin, PhD

College of Pharmacy and Nutrition

University of Saskatchewan

\section{References}

1. Tsuyuki RT, Davies NM. Self-denigration in pharmacy: words to banish from the pharmacy lexicon. Can Pharm J (Ott) 2014;147:197-9.

2. Davies NM, Tsuyuki RT. Self-denigration in pharmacy: actions that should be curtailed. Can Pharm J (Ott) 2014;147:265-6.

3. Merriam-Webster. Allied. Available: www.merriam-webster.com/dictionary/ allied (accessed October 9, 2014).

4. Jensen K. Guidelines for Minor Ailment Prescribing. University of Saskatchewan. Available: www.medsask.usask.ca/professional/guidelines/index.php (accessed October 9, 2014).

5. Government of Saskatchewan. October 23, 2012. Pharmacist prescribing services enhance patient experience. Available: www.gov.sk.ca/ news?newsId=e8089bf4-a68f-4f1a-8b54-b8cb0ad292c4 (accessed October 9, 2014).

6. Perepelkin J. Public opinion of pharmacists and pharmacist prescribing. Can Pharm J (Ott) 2011;144:86-93.

7. Austin Z, Gregory PA, Martin JC. Characterizing the professional relationships of community pharmacists. Res Soc Admin Pharm 2006; 2:533-46.

8. Guirguis LM, Chewning BA. Role theory: literature review and implications for patient-pharmacist interactions. Res Soc Admin Pharm 2005;1:483-507.

9. Alexander A. Pharmacists demonstrate value of pharmacist-provided care via Capitol Hill health fair. Available: www.drugstorenews.com//article/ pharmacists-demonstrate-value-pharmacist-provided-care-capitol-hillhealth-fair (accessed September 19, 2014).

10. Pharmacy Daily. October 2, 2014. Health checks performed by pharmacists for members of NSW Parliament have been hailed as an "enormous success." Available: www.pharmacydaily.com.au/news/parliament-health-checks/36633 (accessed October 3, 2014).

11. National Association of Chain Drug Stores. NACDS RxIMPACT. Available: http://capwiz.com/nacds/home/index (accessed October 9, 2014).

12. National Community Pharmacists Association. NCPA Advocacy Center. Available: www.ncpanet.org/advocacy/advocacy-center (accessed October 9, 2014).

(C) The Author(s) 2014

DOI: $10.1177 / 1715163514561603$ 